\title{
Evaluation of the pozzolanic activity of red ceramic waste using mechanical and physicochemical methods
}

\section{(Avaliação da atividade pozolânica do resíduo de cerâmica vermelha por meio de métodos mecânicos e físico-químicos)}

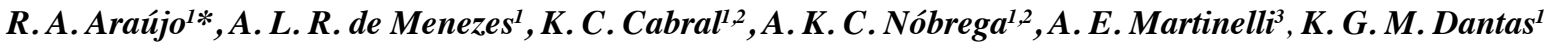 \\ ${ }^{1}$ Universidade Federal do Rio Grande do Norte, Programa de Pós-Graduação em Engenharia Civil, \\ Av. Sen. Salgado Filho 3000, 59064-741, Natal, RN, Brazil \\ ${ }^{2}$ Universidade Federal Rural do Semi-Árido, Angicos, RN, Brazil \\ ${ }^{3}$ Universidade Federal do Rio Grande do Norte, Programa de Pós-Graduação em Ciência e \\ Engenharia dos Materiais, Natal, RN, Brazil
}

\begin{abstract}
Alternative cementitious materials can potentially reduce the environmental impact of the extraction of lime and the hazardous production of Portland cement. Red ceramic waste can be comminuted to fine particles with both filler and pozzolanic activity and used in Portland and lime mortars. This study presents the evaluation of the pozzolanic activity of red ceramic waste by physicochemical and mechanical methods using Portland cement and lime mortars. The evaluated waste depicted high pozzolanic activity and absence of $\mathrm{Na}_{2} \mathrm{O}$, and consumed $32 \%$ of $\mathrm{CaO}$ according to the adapted Chapelle test. The compressive strength recorded in the pozzolanic activity test with lime was 7.1 MPa at 7 days. Moreover, the compressive strength of mixes with $25 \%$ replacement of Portland cement by red ceramic waste was $11 \%$ higher than the reference waste-free composition. The red ceramic waste depicted adequate characteristics to be used in the production of large volumes of Portland and lime mixes commonly employed in the civil construction.
\end{abstract}

Keywords: red ceramic waste, pozzolanic activity, Portland cement, lime mortar.

Resumo

\begin{abstract}
Materiais cimentícios alternativos podem reduzir potencialmente o impacto ambiental da extração de cal e a produção de cimento Portland. Resíduos de cerâmica vermelha podem ser triturados em partículas finas e usados como filler ou adição pozolânica em argamassas de cimento Portland e cal. Este estudo apresenta a avaliação da atividade pozolânica do resíduo de cerâmica vermelha por métodos físico-químicos e mecânicos. O resíduo avaliado apresentou alta atividade pozolânica e ausência de sódio, além de consumir $32 \%$ de CaO conforme o teste Chapelle adaptado. A resistência apresentada no teste de atividade pozolânica com cal foi de 7,1 MPa aos 7 dias. A resistência à compressão de misturas com $25 \%$ de substituição de cimento Portland por resíduo de cerâmica vermelha foi $11 \%$ maior em comparação com a da composição de referência. O resíduo de cerâmica vermelha apresentou características adequadas para uso na produção de grandes volumes de argamassas à base de cimento Portland e cal comumente utilizadas na construção civil.
\end{abstract}

Palavras-chave: resíduo de cerâmica vermelha, atividade pozolânica, cimento Portland, argamassa de cal.

\section{INTRODUCTION}

The production of Portland cement is highly demanding in energy and natural resources, such as clay and limestone, in addition to emitting large volumes of $\mathrm{CO}_{2}$ to the environment. The production of 1 ton of Portland cement emits 0.94 ton of $\mathrm{CO}_{2}$ and consumes more than 1.5 ton of raw materials and 2.93-6.28 GJ of thermal energy, in addition to 65 to $141 \mathrm{kWh}$ of electric power $[1,2]$. The use of sustainable materials with pozzolanic activity may considerably reduce the energetic and environmental impact of the production of

*risia_amaral@hotmail.com

(D) https://orcid.org/0000-0001-9265-9459 cementitious materials. In addition, the use of pozzolans can also improve the fresh and hardened properties of mortars, in addition to controlling the heat of hydration and reducing creep and shrinkage of mortars and concrete [2-7]. Wastes from the red ceramic industry currently account for up to $7 \%$ of the global production of ceramic materials, which implies that millions of tons of calcined clays are discarded yearly [8-10]. In the Roman period, the brick powder was often used in the absence of natural pozzolans, providing hydraulic characteristics and sometimes waterproofing properties to aerated lime mortars [11]. Mixes made from thermally treated clays obtained from ground byproducts are also known to be quite durable and reliable and were used for many centuries. Evidence of that is provided by historic 
buildings and archaeological sites, indicating their longevity $[8,12]$.

The pozzolanic activity of ceramic wastes is related to the amorphous or disordered structure of aluminosilicates, resulted from heat-treatments in the range of 600 to $900{ }^{\circ} \mathrm{C}$ [3]. The use of large volumes of solid wastes as alternative raw materials saves natural non-renewable natural resources and energy, significantly contributing to the preservation of landfill areas and the environment [13]. On the other hand, the wide use of pozzolanic additions to cement, e.g., those containing heavy metals or hazardous organics, must be evaluated. Other pozzolans may also contain high concentrations of soluble salts or alkalis that may affect the durability of cementing materials [14]. The pozzolanic potential of the use of ceramic wastes in Portland and lime mortars has been investigated $[8-12,15,16]$. Mineral additions must meet certain chemical and physical requirements to be considered pozzolans [17, 18], including a maximum of $4.0 \% \mathrm{SO}_{3}$ and $1.5 \%$ alkali equivalent. The sum $\mathrm{SiO}_{2}+\mathrm{Al}_{2} \mathrm{O}_{3}+\mathrm{Fe}_{2} \mathrm{O}_{3}$ must exceed $70 \%$. The strength activity index with Portland cement (ratio between the strength of the pozzolan and the reference mix) at 28 days should be at least $90 \%$, according to Brazilian standards $[18,19]$, and $75 \%$ according to ASTM [11]. In addition, the Brazilian standard also requires a pozzolanic activity test using a lime mix whose compressive strength should be greater than 6.0 MPa at 7 days [20]. The pozzolanic activity of calcined clays depends on the nature and amount of clay minerals and impurities present in the composition, on the thermal treatment used in their activation and specific surface obtained upon calcination. High specific surfaces of calcined clay minerals $\left(980-2300 \mathrm{~m}^{2} / \mathrm{kg}\right)$ strongly affect short-term pozzolanic activity, whereas the long-term reaction is ruled by the chemical and mineralogical composition of the amorphous phases presenting in the material [21]. Milling positively affects the properties of secondary raw materials. A relationship between fineness and reactivity has been established from results of $100 \%$ pozzolanic activity index, obtained by milling the waste during $120 \mathrm{~min}$ [22].

It has been also demonstrated that concrete mixes containing calcined clay developed strength similar to reference compositions and exceeding the strength depicted by mixes containing $30 \%$ fly ashes. Refined microstructures and pore structures have been obtained at early ages as a result of the high pozzolanic activity of calcined clays [23]. Powdered ceramic waste also improved the workability retention of concrete mixes and significantly improved their durability [13]. Therefore, the present study aimed at evaluating the composition and morphology of red ceramic wastes milled to $d_{90}<20 \mu \mathrm{m}$ as well as its pozzolanic activity by physicochemical methods and standardized mechanical strength tests.

\section{MATERIALS AND METHODS}

Materials: a red ceramic waste (RCW) was obtained from a local ceramic industry. It consisted of fragments of ceramic roof tiles, discarded by the quality control. The roof tiles were produced by the conventional ceramic process and fired between 830 and $950{ }^{\circ} \mathrm{C}$ for $20 \mathrm{~h}$ in a chamber oven. The waste was a collection of large fragments of various sizes and shapes, from shards to almost whole roof tiles. The reference binder used herein was Portland type III cement [24], due to the absence of pozzolans in its composition and the small amount of additions. The lime used was hydrated type $\mathrm{S}$ lime of marine sedimentary origin with $\mathrm{MgO}$ content less than $3.5 \mathrm{wt} \%$. Normalized river bed sand [25] was purchased in the local commerce. The performance index test with Portland cement [19] required a water to cement ratio of 0.48 , resulting in low consistency index that prevented the correct densification of the mortar. This behavior was corrected by adding $2 \mathrm{wt} \%$ of a Rheomix 701 plasticizer (based on synthetic resins) to the mixture.

Red ceramic waste handling: initially, $5 \mathrm{~kg}$ of red ceramic waste was comminuted in a Los Angeles abrasion test apparatus for 20 min with an abrasive load of 16 cast iron balls in a cylindrical drum. A small aggregate was obtained, sieved at $4.8 \mathrm{~mm}$ and further ball milled in a $5 \mathrm{~L}$ drum. $55 \%$ of the volume of the drum was filled with $2 \mathrm{~kg}$ of waste and alumina beads of varying sizes. Laser diffraction particle size analysis was carried out using a Cilas 920 set-up. Particles smaller than $75 \mu \mathrm{m}$, adequate for mineral addition to mortars, were obtained. After milling, the material was oven dried for $24 \mathrm{~h}$ at $110{ }^{\circ} \mathrm{C}$ and then stored in sealed containers.

Pozzolanic activity index with Portland cement: cylindrical specimens with $50 \mathrm{~mm}$ diameter and $100 \mathrm{~mm}$ height were molded. The pozzolanic activity in cement mortars was calculated by the ratio between the average compressive strength at 28 days of a mortar with $25 \mathrm{wt} \%$ of red ceramic waste, designated herein as SUB, and a reference mortar, designated as REF, which was free of waste. Sand and water were used in both mixes $[18,19]$. The mass ratio used was $1: 3$ and the water to cement ratio was 0.48 . A superplasticizer was used to maintain the consistency of the mortars suitable for the densification of the specimens. After mixing, the specimens were kept in the molds for the first $24 \mathrm{~h}$. They were then demolded and cured in a saturated solution of calcium hydroxide until the age of rupture. The compressive strength was determined at 7 and 28 days, and three specimens were tested at each age $[18,19]$.

Pozzolanic activity index with hydrated lime: the pozzolanic activity with hydrated lime was also used to evaluate the reactivity of the waste [20]. In this method, the mortar must contain one part by weight of calcium hydroxide and double of this amount of pozzolanic material. The mass ratio of calcium hydroxide: pozzolan: sand used was 1:2.51:9. Water was adjusted to result in the consistency

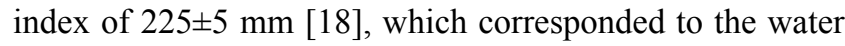
to binder ratio of 0.70 . Three specimens $(50 \mathrm{~mm}$ diameter x $100 \mathrm{~mm}$ height) cured for 7 days were molded. During the first $24 \pm 2 \mathrm{~h}$, the samples remained at $23 \pm 2{ }^{\circ} \mathrm{C}$. The temperature was then increased to $55 \pm 2{ }^{\circ} \mathrm{C}$ during additional $144 \pm 2 \mathrm{~h}$. After demolding, the compressive rupture load was 
determined in a Shimadzu AG-300kNx plus press.

Adapted Chapelle test: the Chapelle test [26] is used to measure the reduction of $\mathrm{Ca}(\mathrm{OH})_{2}$ by a combination with siliceous materials or aluminosilicates present in pozzolans. The test used herein consisted of an adaptation to the Chapelle test described in [27], named Chapelle LCPC. Accordingly [27, 28], a mixture of $3 \mathrm{~g}$ of $\mathrm{CaO}$ and $1 \mathrm{~g}$ of pozzolan (instead of $2 \mathrm{~g}$ of $\mathrm{CaO}$ in [26]) was placed in a plastic Erlenmeyer flask with $250 \mathrm{~mL}$ of distilled and decarbonized water and heated at $40{ }^{\circ} \mathrm{C}$ for $96 \mathrm{~h}$. A control mixture was made under the same conditions but containing only $\mathrm{CaO}$. Finally, the material was filtered and the residue was subjected to thermogravimetric analysis to quantify the consumption of calcium hydroxide.

Materials characterization: the chemical composition of the red ceramic waste and Portland cement were determined by X-ray fluorescence analysis. The chemical characteristics of lime were informed by the manufacturer. The unitary and specific masses of the cementitious materials used were obtained by standard tests [29, 30]. The particle size distribution of the binders was obtained by laser diffraction analysis in a Cilas $920 \mathrm{~L}$ equipment. Scanning electron microscopy (SEM) coupled to energy dispersive spectroscopy (EDS) were performed for morphological and elemental analysis of the waste and mortars. The micrographs were obtained on a Hitachi TM-3000 microscope. The red ceramic waste, Portland cement, and mortars were analyzed by X-ray semi-quantitative fluorescence analyses using a Shimadzu EDX-720 spectrometer. X-ray diffraction (XRD) analyses were performed in samples with particles smaller than $150 \mu \mathrm{m}$ using $\mathrm{CuK} \alpha$ radiation, accelerating voltage of $40 \mathrm{kV}$ and current of $30 \mathrm{~mA}$. The $2 \theta$ range from $5^{\circ}$ to $80^{\circ}$ was scanned at a rate of $5 \% \mathrm{~min}$. The equipment used was a Shimadzu XRD-7000 set-up. Thermogravimetric analysis (TG/DTG) was performed to evaluate the pozzolanic activity of the waste by quantifying the mass loss related to the dehydroxylation of calcium hydroxide of the mortars. The analysis was performed on a TA SDTQ600 set-up under static air from 25 to $950{ }^{\circ} \mathrm{C}$ at a heating rate of $10^{\circ} \mathrm{C} / \mathrm{min}$.

\section{RESULTS AND DISCUSSION}

Waste characterization: the particle size distributions of hydrated lime, Portland cement (CP) and red ceramic waste (RCW) are shown in Fig. 1. Distribution parameters are summarized in Table I. The average diameters obtained were 5.40, 9.50 and $6.12 \mu \mathrm{m}$, respectively. RCW showed the smallest particle size for $10 \%$ and $50 \%$ (D50=3.73 $\mu \mathrm{m}$ ). All powders exhibited similar particle size distribution profiles, suggesting that the comminution process of the RCW was efficient to reproduce the fineness of the other two powders. The maximum diameter of RCW particles after comminution was $36 \mu \mathrm{m}$, which fulfilled the fineness requirement for pozzolans $[17,18]$. Pozzolanic materials should depict less than $20 \%$ and $34 \%$ of their volume of particles of 325 mesh $(45 \mu \mathrm{m})$ size according to Brazilian [18] and international [17] standards, respectively. These characteristics improve the reactivity of the material to form hydration products and its filler effect, thus contributing to the reduction of porosity, restricting the penetration of aggressive agents and the diffusion of deleterious agents, which implies in better mortar durability [3]. In addition to the filler effect, grain size refinement has also been reported [3]. This effect restricts the growth of calcium hydroxide, which together with the consumption of the material in the pozzolanic reaction, increases the resistance to sulfates and carbonates. The susceptibility of calcium hydroxide comes from its lower stability compared to other hydration products, such as $\mathrm{CSH}$ (calcium silicate hydrate) and CASH (calcium aluminate silicate hydrate). It dissolves in contact with sulfates and moisture, thus increasing the porosity of the mixture.

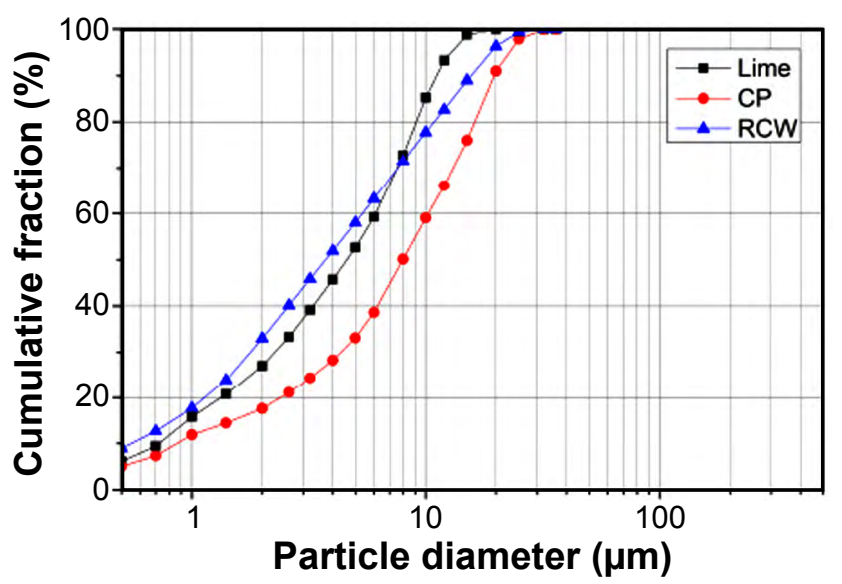

Figure 1: Particle size distribution curves of hydrated lime, Portland cement $(\mathrm{CP})$ and $\mathrm{RCW}$.

[Figura 1: Curvas de distribuição granulométrica da cal hidratada, cimento Portland $(C P)$ e resíduo de cerâmica vermelha $(R C W)$.]

Table I - Results $(\mu \mathrm{m})$ of the particle size distribution test for binders (range 0.30-400 $\mu \mathrm{m}$ ).

[Tabela I - Resultados $(\mu \mathrm{m})$ do teste de distribuição de tamanho de partículas para os ligantes (faixa 0,30-400 $\mu \mathrm{m}$ ).]

\begin{tabular}{cccc}
\hline Size & RCW & CP & Lime \\
\hline D10 & 0.55 & 0.86 & 0.72 \\
D50 & 3.73 & 7.98 & 4.60 \\
D90 & 15.61 & 19.64 & 11.14 \\
Average & 6.12 & 9.50 & 5.40 \\
Median & 4.60 & 5.0 & 3.60 \\
Mode & 7.0 & 17.0 & 10.0 \\
\hline
\end{tabular}

The unit mass, specific mass and surface area of the materials are listed in Table II. The values corresponding to Portland cement and lime were compatible with those provided by the manufacturers. It was noticed that the unit and specific masses of RCW were smaller than those of the cement, further suggesting the filler ability of the waste in cementitious matrices. The surface area of RCW $\left(2.11 \mathrm{~m}^{2} / \mathrm{g}\right)$ was higher than that of the Portland cement $\left(1.15 \mathrm{~m}^{2} / \mathrm{g}\right)$, which was in good agreement with the particle size distribution 
illustrated in Fig. 1. Both fineness and surface area of $\mathrm{RCW}$ increase the reactivity and kinetics of the pozzolanic reaction.

Table II - Physical characteristics of binders. [Tabela II - Características físicas dos ligantes.]

\begin{tabular}{cccc}
\hline Material & $\begin{array}{c}\text { Unit mass } \\
\left(\mathrm{g} / \mathrm{cm}^{3}\right)\end{array}$ & $\begin{array}{c}\text { Specific mass } \\
\left(\mathrm{g} / \mathrm{cm}^{3}\right)\end{array}$ & $\begin{array}{c}\text { Surface area } \\
\left(\mathrm{m}^{2} / \mathrm{g}\right)\end{array}$ \\
\hline $\mathrm{CP}$ & 1.00 & 3.05 & 1.15 \\
$\mathrm{RCW}$ & 0.71 & 2.75 & 2.11 \\
Hydrated lime & 0.41 & 2.19 & 6.74 \\
\hline
\end{tabular}

The chemical composition of RCW, Portland cement (CP) and lime are shown in Table III. RCW contained signifi cant amounts of equivalent hydraulic oxides, i.e., $\mathrm{SiO}_{2}, \mathrm{Al}_{2} \mathrm{O}_{3}$ and $\mathrm{Fe}_{2} \mathrm{O}_{3}$. The sum of these components added approximately $90 \%$, which was above the minimum required for pozzolans $[17,18]$. Smaller contents of $\mathrm{MgO}$ and $\mathrm{K}_{2} \mathrm{O}$ were also observed. The small content of $\mathrm{SO}_{3}(0.01$ $\mathrm{wt} \%)$ is desirable for the production of mortars and concrete mixes susceptible to sulfate expansion. Higher contents of $\mathrm{SO}_{3}(0.6 \%$ to $2.04 \%)$ have been reported for ceramic and clay materials [7, 9-11, 13-16]. The alkali content of the ceramic waste evaluated herein was also different from that of similar pozzolanic wastes [7, 9-11, 15, 16, 31-33], whose $\mathrm{Na}_{2} \mathrm{O}$ levels ranged between $0.14 \%$ and $3.80 \%$. Sodium-free pozzolans are more appropriate since high concentrations of $\mathrm{Na}_{2} \mathrm{O}$ stimulate alkali-aggregate reactions in concrete and mortars, which contributes to the expansion of the mix. On the other hand, the presence of $\mathrm{K}_{2} \mathrm{O}$ does not significantly affect expansion [34]. Therefore, the composition of the waste investigated contributes to the durability of the cementitious compounds, especially those subjected to alkali-aggregate reactions.

Scanning electron micrographs of the RCW sample are shown in Fig. 2. It was seen that its microstructure contained large angular particles (arrows in Fig. 2a), reported as quartz surrounded by feldspars. Both phases are commonly coated by fine fragments of fired clays, titanium and iron oxides [31]. EDS analysis of the area circled in Fig. 2b revealed the predominant presence of silicon, aluminum, iron and oxygen, which was consistent with the composition and lamellar morphology of clay minerals present in RCW. The mineralogical composition of RCW crystalline phases is shown in Fig. 3. The presence of quartz, anorthite and, to a lesser degree, hematite and phlogopite were identified. The presence of anorthite was associated with high levels

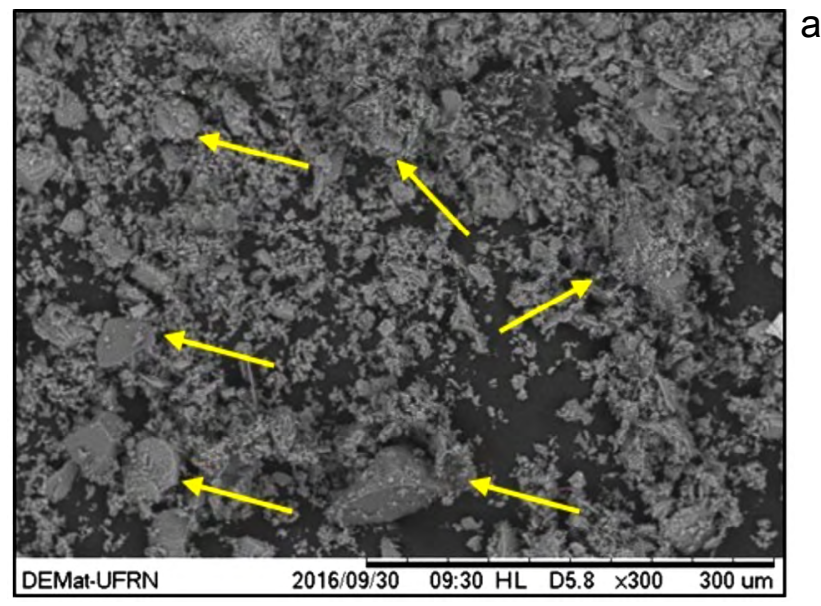

a)

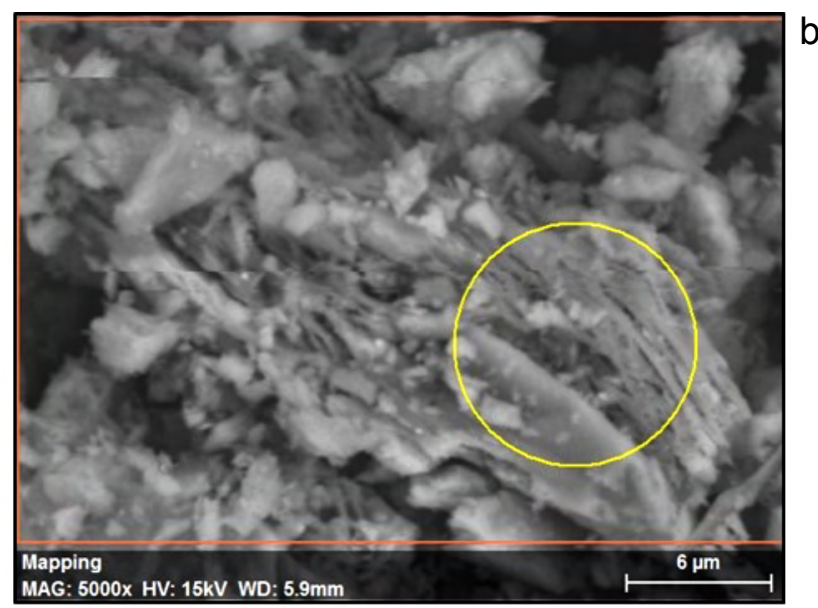

Figure 2: Scanning electron micrographs of the RCW sample: a) arrows indicate the large angular particles; b) circled area shows the lamellar morphology of clay minerals present in RCW.

[Figura 2: Micrografias eletrônicas de varredura da amostra de RCW: a) setas indicam grandes partículas angulares; b) área circulada mostra a morfologia lamelar dos argilominerais presentes no $R C W$.]

of calcium and magnesium. It has been reported that the presence of mica in the composition of RCW is confirmed when the $\mathrm{K}_{2} \mathrm{O}$ content is above $1.18 \%$ [35]. Significant amounts of $\mathrm{Mg}$ and $\mathrm{Ca}$ may be associated with muscovite and anorthite clay [31]. Phlogopite, $\mathrm{KMg}_{3}\left(\mathrm{AlSi}_{3} \mathrm{O}_{10}\right)(\mathrm{OH})_{2}$, is a mineral from the group of micas, which is part of the phyllosilicate family, that includes minerals with pozzolanic activity, such as illite and montmorillonite [36].

Adapted Chapelle test: the thermogravimetric analysis used to quantify the content of calcium hydroxide consumed by pozzolans in the adapted Chapelle test [27] is shown in

Table III - Chemical composition (wt $\%$ ) of binders in terms of oxides.

[Tabela III - Composição química (\% em massa) dos ligantes em óxidos.]

\begin{tabular}{cccccccccccc}
\hline Material & $\mathrm{CaO}$ & $\mathrm{SiO}_{2}$ & $\mathrm{Fe}_{2} \mathrm{O}_{3}$ & $\mathrm{Al}_{2} \mathrm{O}_{3}$ & $\mathrm{~K}_{2} \mathrm{O}$ & $\mathrm{Na}_{2} \mathrm{O}$ & $\mathrm{SO}_{3}$ & $\mathrm{MgO}$ & $\mathrm{SrO}$ & $\mathrm{TiO}_{2}$ & $\mathrm{Ca}(\mathrm{OH})_{2}$ \\
\hline $\mathrm{RCW}$ & 0.99 & 42.33 & 22.63 & 24.52 & 3.47 & 0.0 & 0.01 & 3.99 & 0.0 & 1.47 & - \\
$\mathrm{CP}$ & 77.59 & 7.53 & 7.99 & 2.67 & 0.69 & 0.0 & 1.48 & 0.82 & 0.46 & 0.20 & - \\
Hydrated lime & - & 0.0 & - & - & - & - & - & 4.0 & - & - & $90-98$ \\
\hline
\end{tabular}




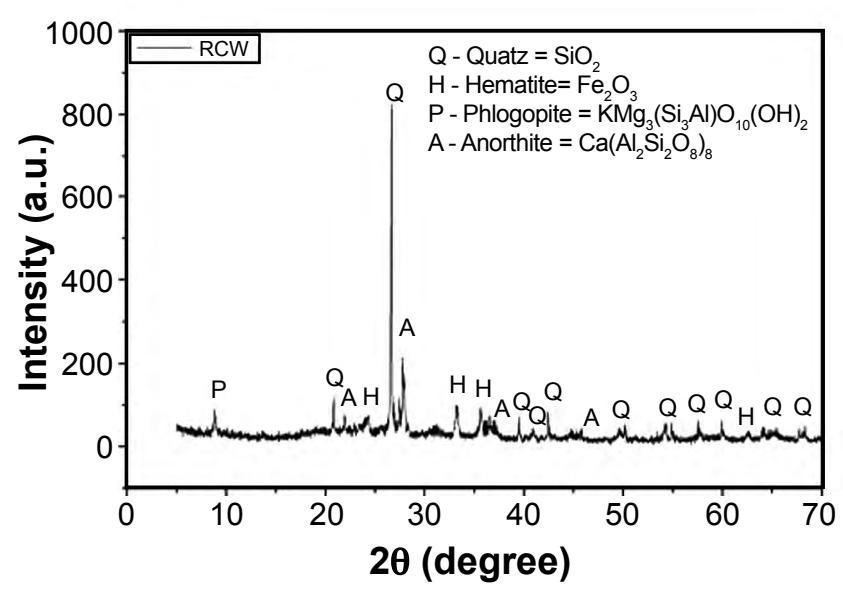

Figure 3: X-ray diffraction pattern showing the mineralogical composition of RCW.

[Figura 3: Difratograma de raios X mostrando a composição mineralógica do $R C W$.]
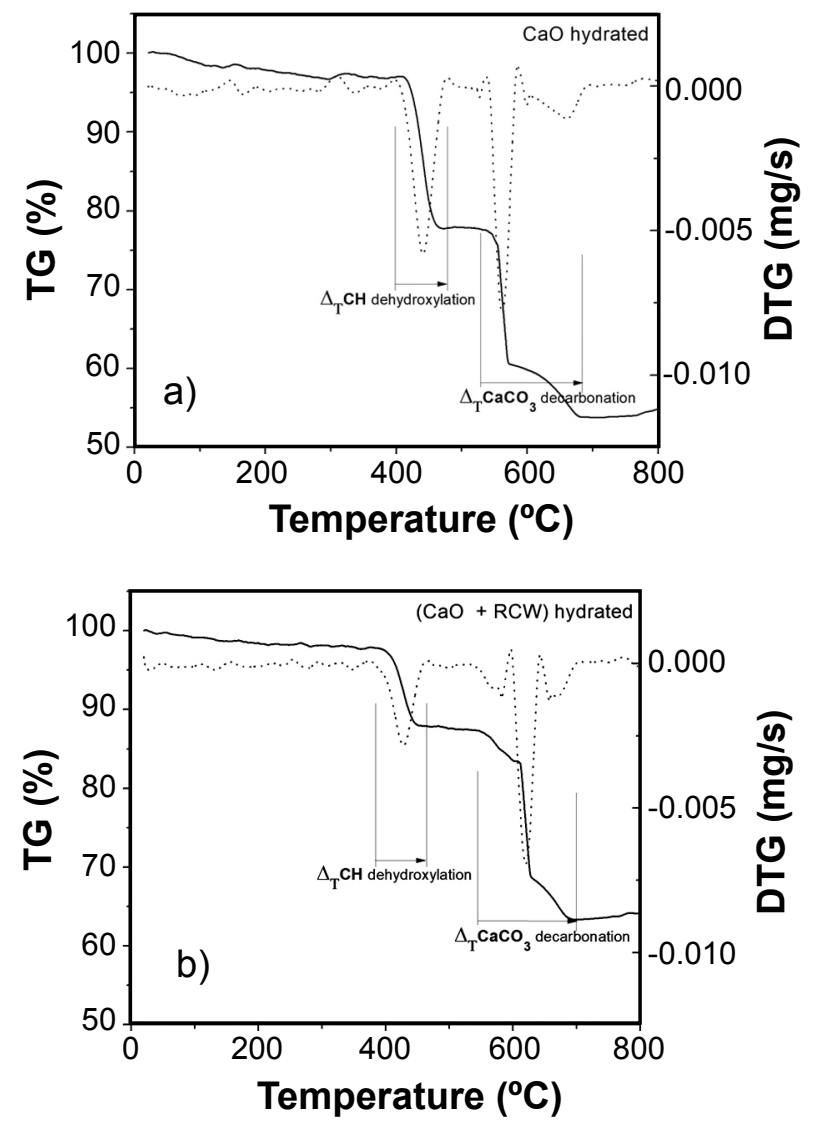

Figure 4: TG/DTG curves of filtered residue from adapted Chapelle test of: a) reference $\mathrm{Ca}(\mathrm{OH})_{2}$; and b) $\mathrm{Ca}(\mathrm{OH})_{2}$ with $\mathrm{RCW}$.

[Figura 4: Curvas de TG/DTG do resíduo filtrado do ensaio Chapelle adaptado de: a) $\mathrm{Ca}(\mathrm{OH})_{2}$ de referência; e b) $\mathrm{Ca}(\mathrm{OH})_{2}$ com RCW.]

Fig. 4. The mass loss corresponding to the dehydroxylation of calcium hydroxide was in the range of 350 to $500{ }^{\circ} \mathrm{C}$. A significant reduction in mass loss of calcium hydroxide, related to the pozzolanic activity of the material, can be seen comparing Figs. 4a and 4b: $32 \%$ of $\mathrm{CaO}$ was consumed by the $\mathrm{RCW}$ during 4 days at $40{ }^{\circ} \mathrm{C}$. Taking into account that the $\mathrm{CaO}$ :pozzolan ratio was 3:1, it can be established that $1 \mathrm{~g}$ of $\mathrm{RCW}$ reacted with $1 \mathrm{~g}$ of $\mathrm{CaO}$. The reactivity parameters established in $[27,28]$, which are in good agreement with those in [25], indicated that $32 \%$ consumption of $\mathrm{CaO}$ in the reaction corresponded to high pozzolanicity, with more than $700 \mathrm{mg}$ of $\mathrm{Ca}(\mathrm{OH})_{2}$ consumed.

Pozzolanic activity in Portland cement mortars: the strength of the mortars obtained in the pozzolanic test [17-19] is shown in Fig. 5. At 7 days, the compressive strength of the SUB mortar (with RCW) was $18.2 \%$ lower than that of the reference mortar (REF). The strength loss was proportional to the amount of Portland cement in the mortar. Since the kinetics of the pozzolanic reaction is sluggish compared to that of the hydration of Portland cement, the rate of heat loss and strength increase is also slow [3]. Between 7 and 28 days, the increase in the strength of the SUB mortar significantly exceeded that of the reference mortar, resulting in a 28-day strength 1.11 times that of the reference mortar. The pozzolanic effect was then clear. This method to assess the pozzolanic activity with Portland cement complies with the specifications of the corresponding standards [17, 19]. The X-ray diffractograms for the REF and SUB mortars are shown in Fig. 6. At 7 days, ettringite was identified in both mortars. After 28 days, this phase was not detected, as a result of its transformation to monosulphate. The hydration of calcium silicates was confirmed by the decrease in the intensity of the $\mathrm{C}_{2} \mathrm{~S}$ peak (6) at 28 days. The $\mathrm{C}_{2} \mathrm{~S}$ phase in the XRD pattern of the reference mortar (REF) indicated the presence of non-hydrated clinker grains. The hydration of this phase was responsible for the formation of $\mathrm{CSH}$. As the hydration progressed, the intensity of the $\mathrm{C}_{2} \mathrm{~S}$ peak reduced along with the increase in the intensity of the peaks of the CSH phase, as was observed at 28 days. In Figs. $6 \mathrm{c}$ and $6 \mathrm{~d}$, it can be seen that, in addition to the phases detected in the reference mortar, the SUB mortar revealed the formation of gismondine $\left(\mathrm{CaAl}_{2} \mathrm{Si}_{2} \mathrm{O}_{8} \cdot 4 \mathrm{H}_{2} \mathrm{O}\right.$, peak 7$)$ at all ages. Gismondine is a hydration product derived from

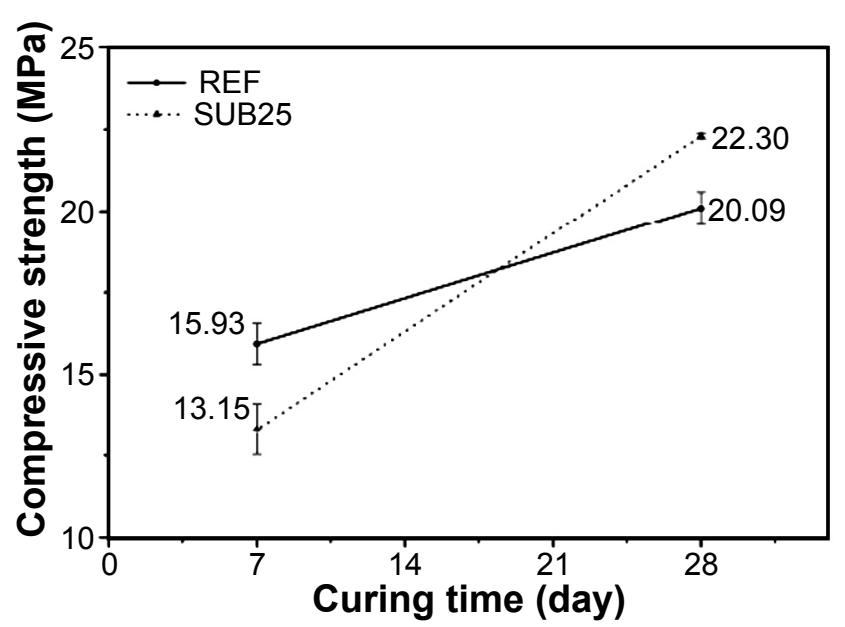

Figure 5: Compressive strength of mortars at 7 and 28 days.

[Figura 5: Resistência à compressão das argamassas aos 7 e 28 dias.] 

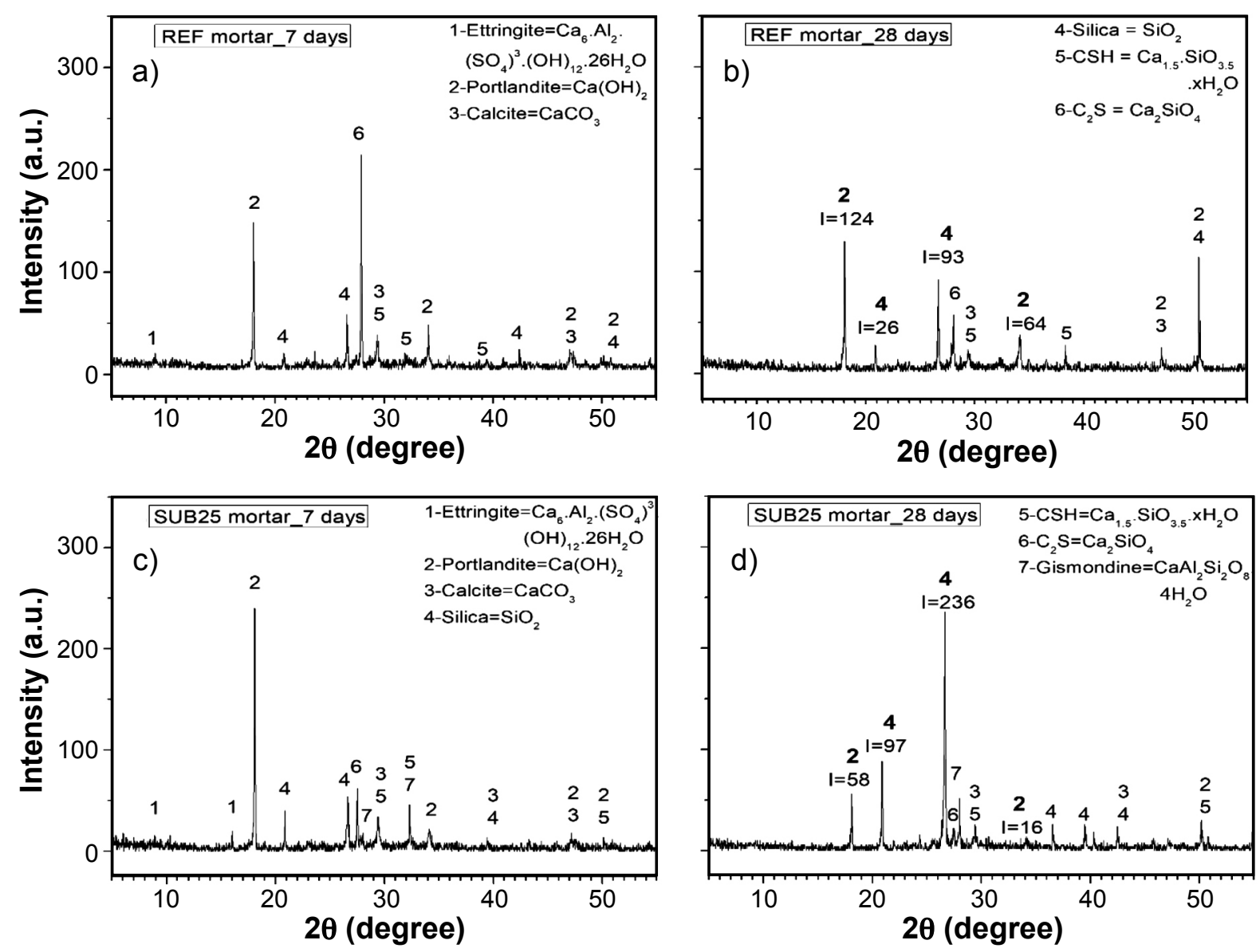

Figure 6: XRD patterns of mortars: reference (REF) at 7 (a) and 28 (b) days; and with 25\% RCW (SUB) at 7 (c) and 28 (d) days. [Figura 6: Padrões de DRX de argamassas: de referência (REF) aos 7 (a) e 28 (b) dias; e com 25\% RCW (SUB) aos 7 (c) e 28 (d) dias.]

the thermodynamically stable pozzolanic reaction that can precipitate at room temperature from the reaction of $\mathrm{C}_{2} \mathrm{~S}$ or CSH with released $\mathrm{AH}_{3}$ or another calcium aluminate in the hydration process $[37,38]$. There was an increase in the intensity of the gismondine peak $\left(2 \theta=26.67^{\circ}\right)$ at 28 days, indicating that during this period its formation continued as a result of the pozzolanic activity. Therefore, the gain in strength shown in Fig. 5 was not only due to the hydration of the CSH gel, since the formation of gismondine is partially responsible for the compaction of the slurry [39].

In order to better understand the pozzolanic reaction by XRD, data from each group of mortars with different degrees of hydration were compared. It has been reported that the intensity of the portlandite peaks $\left(2 \theta=18.08^{\circ}\right.$ and $\left.34.12^{\circ}\right)$ increases with respect to that of quartz, showing a maximum at 28 days. This indicates the hydration of calcium silicates in the first age [31], which can be corroborated by the analysis of the diffractogram of the reference mortar (Figs. 6a and $6 b)$ that showed an increase in the intensity of the peaks at $2 \theta=18.08^{\circ}$ and $34.12^{\circ}$. Additionally, for SUB mortars (Figs . $6 \mathrm{c}$ and $6 \mathrm{~d}$ ), the intensity of the portlandite peak (2) at 28 days decreased due to its consumption in the pozzolanic reaction. The evolution of $\mathrm{Ca}(\mathrm{OH})_{2}$ content as the hydration reaction took place in each sample was estimated from the intensity of its diffraction peaks. At each age, the reference mortar (Figs. 6a and 6b) had a higher amount of $\mathrm{Ca}(\mathrm{OH})_{2}$ comparing to mortars containing red ceramic waste (Figs. $6 \mathrm{c}$ and $6 \mathrm{~d}$ ). This was expected and reinforced the evidence of the pozzolanic reaction. It was observed that in the mortar containing $25 \% \mathrm{RCW}$ (SUB), the quartz diffraction peaks were significantly more intense than those in the REF mortar. On the other hand, the amount of portlandite in the SUB mortar was lower than in the REF mortar. This is typical of the pozzolanic reaction of RCW [7]. It was also seen that the substitution of $25 \%$ of Portland cement by RCW reduced the intensity of the two most intense peaks of calcium hydroxide $\left(2 \theta=18.08^{\circ}\right.$ and $\left.34.12^{\circ}\right)$. It should be pointed out that the hydration products formed from the pozzolanic reaction are resistant to weathering, such as sulfate attack [7, 40-45].

The TG/DTG plots corresponding to the REF and SUB mortars after 7 and 28 days are shown in Fig. 7. A typical peak related to $\mathrm{CSH}$ and $\mathrm{CA}_{2} \mathrm{SH}_{4}$ (gismondine) was detected from 120 to $180^{\circ} \mathrm{C}$ [44]. However, below $200^{\circ} \mathrm{C}$, the peaks of CSH, ettringite and chemically bound water overlap [45]. The formation of superimposed peaks in the DTG plot is accompanied by a weight loss in the TG plot, similar for both REF and SUB mortars. At about $420^{\circ} \mathrm{C}$, a typical peak was detected and was correlated with the dehydration of calcium 

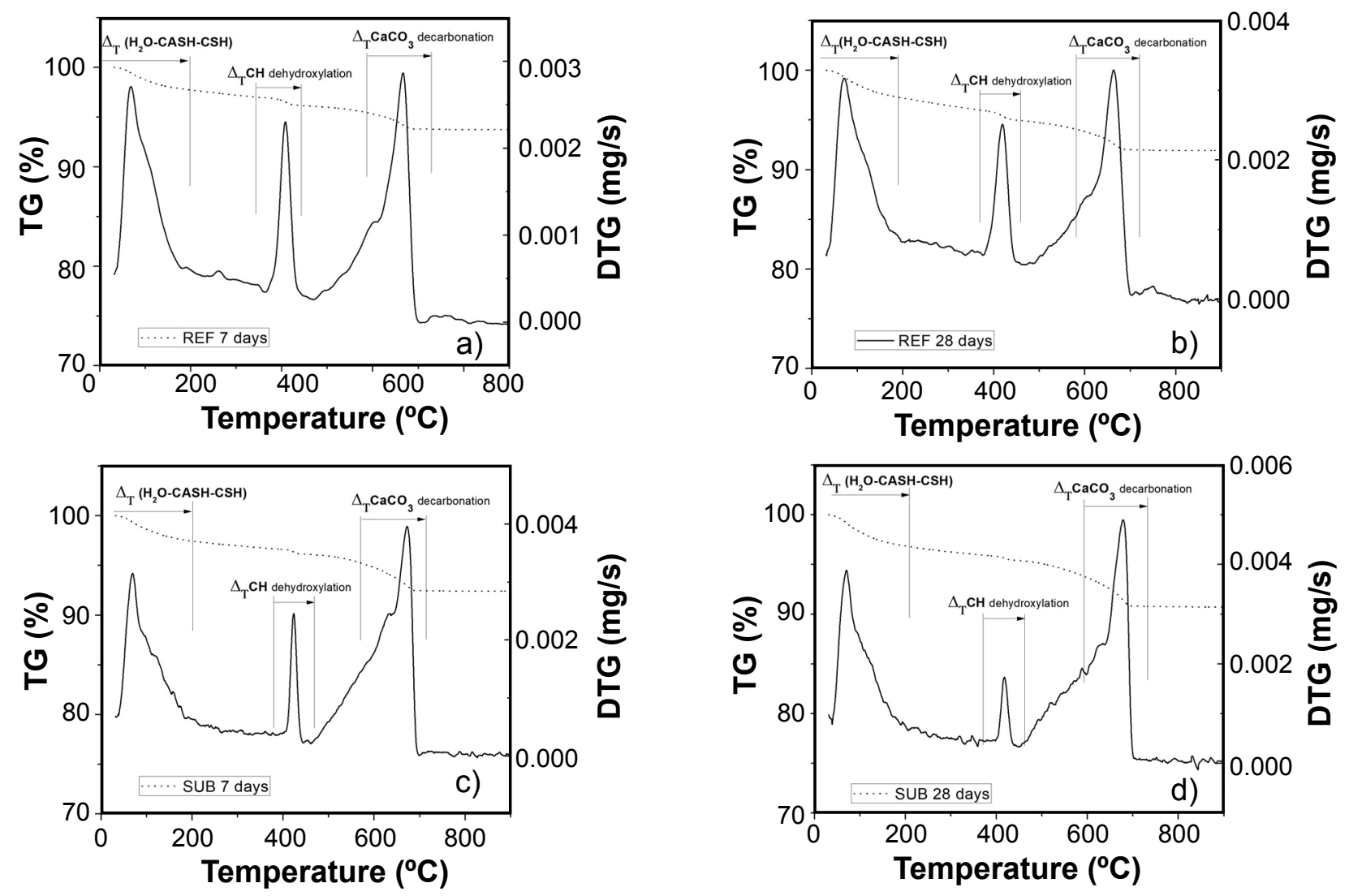

Figure 7: TG/DTG curves of mortars: reference (REF) at 7 (a) and 28 (b) days; and with 25\% RCW (SUB) at 7 (c) and 28 (d) days. [Figura 7: Curvas de TG/DTG de argamassas: de referência (REF) aos 7 (a) e 28 (b) dias; e com 25\% RCW (SUB) aos 7 (c) e $28(d)$ dias.]

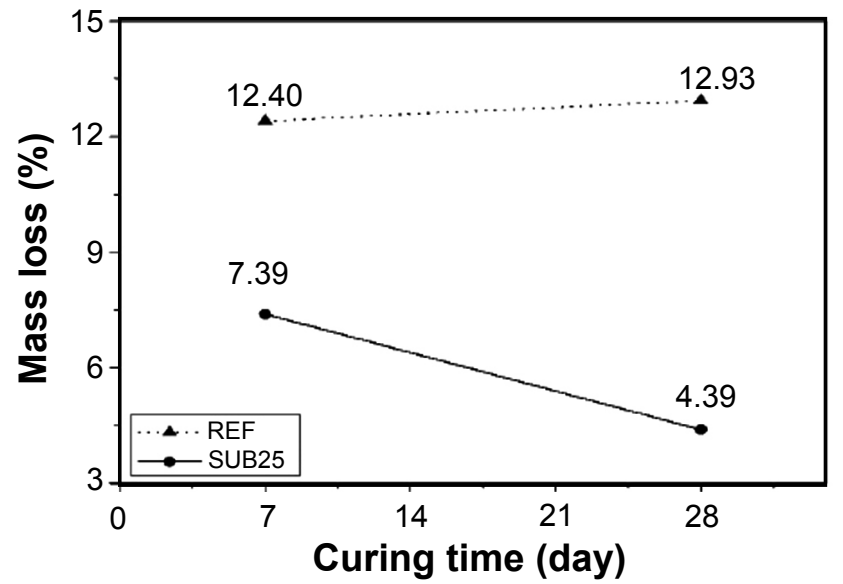

Figure 8: Mass loss of $\mathrm{CH}$ in the mortars.

[Figura 8: Perda de massa de CH nas argamassas.]

hydroxide (Figs. 7c and 7d). It exhibited a decreasing trend with curing time for the SUB mortars. Therefore, the consumption of calcium hydroxide over time confirmed the reactivity of RCW, since the pozzolanic activity suggested higher consumption of portlandite than that of the hydration of $\mathrm{C}_{2} \mathrm{~S}$. Finally, at about $690{ }^{\circ} \mathrm{C}$, the thermal analysis revealed the decarbonation of $\mathrm{CaCO}_{3}$. The mass loss of the mortars is shown in Fig. 8. Since the contribution of $\mathrm{CO}_{2}$ evolution remained nearly constant at all ages, it has been suggested that $\mathrm{CaCO}_{3}$ did not participate in the reactions [44], as it was observed in the DTG of all four mortars. It was also noticed that the mass loss corresponding to the dehydroxylation of portlandite was significantly lower for all ages in the SUB mortar, which can also be attributed to the pozzolanic activity.

Pozzolanic activity in lime mortars: the average compressive strength of mortars used in the pozzolanic activity test [18] with lime was $7.1 \pm 0.6 \mathrm{MPa}$ at 7 days, which complied with the minimum of $6 \mathrm{MPa}$ required by the standard for pozzolanic additions [18]. The strength of lime mortars was attributed to the formation of $\mathrm{CSH}$ and $\mathrm{CASH}$ due to the reaction of reactive aluminosilicate phases present in the RCW with $\mathrm{Ca}^{2+}$ from the dissolution of hydrated lime in aqueous medium [7]. The result of the pozzolanic activity with lime was similar to that reported elsewhere, with values ranging from 7 to $8 \mathrm{MPa}$ [32]. The XRD plot of the mortar formulated from hydrated lime and RCW after curing for 7 days is shown in Fig. 9. The presence of CSH and CASH hydration products was identified. CASH occurred as gismondine $\left(2 \theta=8.78^{\circ}\right.$ and $\left.27.96^{\circ}\right)$ and presented higher crystallinity compared to $\mathrm{CSH}$, according to the peak at $2 \theta=50.03^{\circ}$, shown in the XRD pattern. It is noteworthy that the intensity of the major peak of portlandite $-\mathrm{Ca}(\mathrm{OH})_{2}$ $\left(2 \theta=47.36^{\circ}\right)$, as well as that of the $\mathrm{CaCO}_{3}\left(2 \theta=29.30^{\circ}\right)$, was 


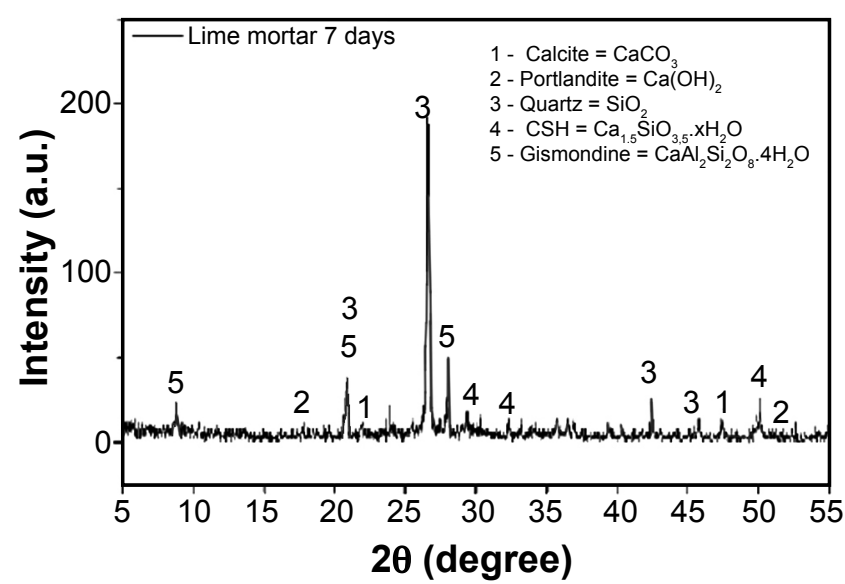

Figure 9: XRD pattern of hydrated lime mortar.

[Figura 9: Padrão de DRX da argamassa de cal hidratada.]

low. The transformation of portlandite was responsible for the formation of gismondine and calcite, the latter due to atmospheric carbonation [46].

The thermal analysis (TG/DTG) of the lime mortars containing RCW is shown in Fig. 10. At 7 days of curing, the lime mortar and $\mathrm{RCW}$ depicted a peak at $\sim 120^{\circ} \mathrm{C}$, indicating the presence of $\mathrm{CSH}$ and $\mathrm{CASH}$. The mass loss for these compounds was $6.68 \%$. In addition, the characteristic peak of dehydration of $\mathrm{Ca}(\mathrm{OH})_{2}$ was detected at about $410^{\circ} \mathrm{C}$, with a relative weight loss of $4.97 \%$. Contrary to the observed by thermal analysis, it has been reported that non-reactive limestone filler depicts the lower mass loss of combined water $\left(0-200^{\circ} \mathrm{C}\right)$ and higher mass loss corresponding to the decomposition of calcium hydroxide $\left(350-450{ }^{\circ} \mathrm{C}\right)$, which

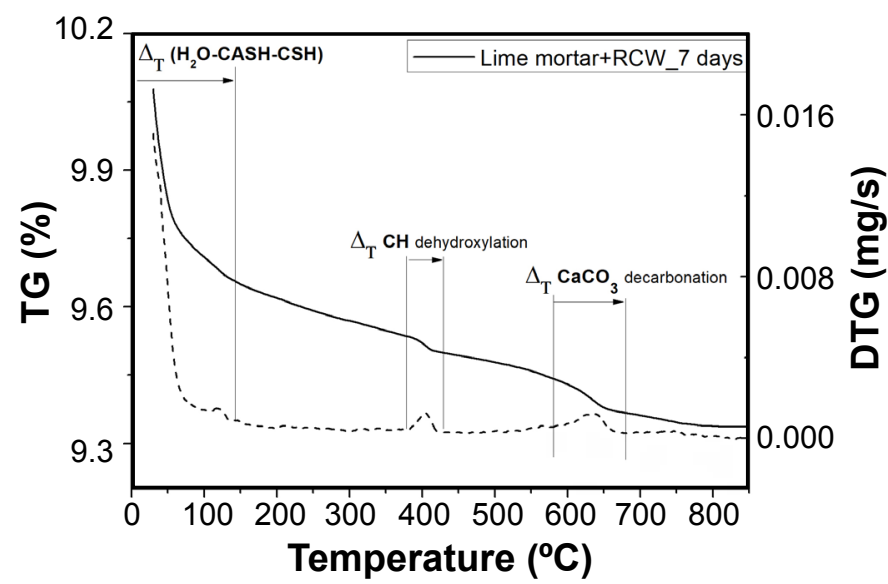

Figure 10: TG/DTG curves of lime mortar with RCW.

[Figura 10: Curvas de TG/DTG da argamassa de cal com RCW.]

corroborated the pozzolanic activity of RCW [47].

\section{CONCLUSIONS}

Red ceramic waste (RCW) was successfully collected and comminuted to fines of $\sim 5 \mu \mathrm{m}$, compatible with the particle sizes of Portland cement and lime. The RCW material was rich in silica, aluminum and iron oxides, but depleted in alkalis, and depicted physicochemical characteristics of both filler and pozzolanic material. According to the adapted Chapelle test, $1 \mathrm{~g}$ of the waste consumed $32 \%$ of $\mathrm{CaO}$. The pozzolanic activity of the waste in Portland mortar at 28 days was $11 \%$ higher than the reference value, which satisfied the minimum requirement for pozzolanic activity ( $\geq 90 \%$ of the reference value). The strength of lime mortars with waste reached $7.13 \mathrm{MPa}$, higher than the required value of $6 \mathrm{MPa}$. The results presented herein indicated that milled red ceramic waste can be used as pozzolanic material in both Portland mixes and lime mortars.

\section{ACKNOWLEDGMENT}

This study was financed in part by the Coordenação de Aperfeiçoamento de Pessoal de Nível Superior - Brasil (CAPES) - Finance Code 001.

\section{REFERENCES}

[1] F. Pacheco-Torgal, Z. Abdollahnejad, S. Miraldo, M. Kheradmand, in "Handbook of low carbon concrete", Elsevier, Cambridge (2017) 195.

[2] F.N. Stafford, F. Raupp-Pereira, J.A. Labrincha, D. Hotza, J. Clean. Prod. 137 (2016) 1293.

[3] P.K. Mehta, P.J.M. Monteiro, Concrete: microstructure, properties and materials, $2^{\text {nd }}$ ed., IBRACON, S. Paulo (2014).

[4] A.A. Ramezanianpour, H.B. Joveing, Constr. Build. Mater. 30 (2012) 470.

[5] Y. Senhadji, G. Escadeillas, M. Mouli, H. Khelafi, Benosman, Powder Technol. 254 (2014) 314.

[6] M. Antoni, J. Rossen, F. Martirena, K. Scrivener, Cem. Concr. Res. 42, 12 (2012) 1579.

[7] E. Navrátilová, P. Rovnaníková, Constr. Build. Mater. 120 (2016) 530.

[8] M. Theodoridou, I. Ioannou, M. Philokyprou, J.Archaeol. Sci. 40, 8 (2013) 3263.

[9] E. Garcia, M. Cabral Junior, V.A. Quarcioni, F.F. Chotoli, Cerâmica 61, 358 (2015) 251.

[10] F. Pacheco-Torgal, S. Jalali, Constr. Build. Mater. 24, 5 (2010) 832.

[11] G. Matias, P. Faria, I. Torres, Constr. Build. Mater. 73 (2014) 523.

[12] E. Vejmelková, M. Keppert, P. Rovnaníková, Z. Keršner, R. Černý, Compos. Part B Eng. 43, 8 (2012) 3534. [13] A.S. El-Dieb, D.M. Kanaan, Sustainable Mater. Technol. 17 (2018) 1.

[14] M. Záleská, M. Pavlíková, Z. Pavlík, O. Jankovský, J. Pokorný, V. Tydlitát, P. Svora, R. Černý, Constr. Build. Mater. 160 (2018) 106.

[15] C.M.F. Vieira, E.T.A. Souza, S.N. Monteiro, Cerâmica 50, 315 (2004) 254.

[16] H. Li, L. Dong, Z. Jiang, X. Yang, Z. Yang, J. Clean. Prod. 133 (2016) 1017.

[17] ASTM C618, "Standard specification for coal fly ash and raw calcined natural pozzolan for use in concrete", Am. Soc. Test. Mater. (2017). 
[18] NBR 12653, "Materiais pozolânicos", Ass. Bras. Norm. Técn., Rio Janeiro (2014).

[19] NBR 5752, "Materiais pozolânicos - determinação do índice de desempenho com cimento Portland aos 28 dias", Ass. Bras. Norm. Técn., Rio Janeiro (2014).

[20] NBR 5751, "Materiais pozolânicos - determinação da atividade pozolânica com cal aos sete dias", Ass. Bras. Norm. Técn., Rio Janeiro (2015).

[21] A. Tironi, M.A. Trezza, A.N. Scian, E.F. Irassar, Cem. Concr. Compos. 37 (2013) 319.

[22] S.A. Memon, M.K. Khan, J. Clean. Prod. 175 (2018) 442.

[23] Y. Dhandapani, T. Sakthivel, M. Santhanam, R. Gettu, R.G. Pillai, Cem. Concr. Res. 107 (2018) 136.

[24] ASTM C150, "Standard specification for Portland cement", Am. Soc. Test. Mater. (2018).

[25] NBR 7214, "Areia normal para ensaio de cimento especificação”, Ass. Bras. Norm. Técn., Rio Janeiro (2015). [26] NF P18-513, "Métakaolin, addition pouzzolanique pour bétons", Ass. Franç. Normal. (2012).

[27] J. Pontes, A.S. Silva, P. Faria, in Anais IV Congr. Constr., Itcons, Coimbra (2012) 1.

[28] J. Pontes, A.S. Silva, P. Faria, Mater. Sci. Forum 730 (2013) 433.

[29] NBR 16605, "Cimento Portland e outros materiais em pó - determinação da massa específica”, Ass. Bras. Norm. Técn., Rio Janeiro (2017).

[30] NBR NM 248, "Agregados - determinação da composição granulométrica”, Ass. Bras. Norm. Técn., Rio Janeiro (2003).

[31] A.E. Lavat, M.A. Trezza, M. Poggi, Waste Manage. 29, 5 (2009) 1666.
[32] A.L. Castro, R.F.C. Santos, K.M. Goncalves, V.A. Quarcioni, Cerâmica 63, 365 (2017) 65.

[33] M.S. Barata, R.S. Angélica, Cerâmica 58, 345 (2012) 36.

[34] C. Drolet, J. Duchesne, B. Fournier, Constr. Build. Mater. 157 (2017) 263.

[35] A. Bentayeb, M. Amouric, J. Olives, A. Dekayir, A. Nadiri, Appl. Clay Sci. 22, 5 (2003) 211.

[36] S. Mohammed, Constr. Build. Mater. 140 (2017) 10.

[37] A. Schackow, D. Stringari, L. Senff, S.L. Correia, A.M. Segadães, Cem. Concr. Compos. 62 (2015) 82.

[38] S. Vichan, R. Rachan, S. Horpibulsuk, Sci. Asia 39, 2 (2013) 186.

[39] S.W. Tang, X.H. Cai, Z. He, H.Y. Shao, Z.J. Li, E. Chen, Constr. Build. Mater. 113 (2016) 939.

[40] M.S. Khan, M. Sohail, N.S. Khattak, M. Sayed, J. Clean. Prod. 139 (2016) 1520.

[41] S. Mohammed, G. Elhem, B. Mekki, Appl. Clay Sci. 132-133 (2016) 711.

[42] M. Antoni, J. Rossen, F. Martirena, K. Scrivener, Cem. Concr. Res. 42, 12 (2012) 1579.

[43] E. Vejmelková, M. Keppert, P. Rovnaníková, Z. Keršner, R. Černý, Cem. Concr. Compos. 34, 4 (2012) 486. [44] A. Moropoulou, A. Bakolas, E. Aggelakopoulou, Thermochim. Acta 420, 1-2 (2004) 135.

[45] M.A. Chikouche, E. Ghorbel, M. Bibi, Constr. Build. Mater. 106 (2016) 330.

[46] S. Antiohos, S. Tsimas, Cem. Concr. Res. 34, 5 (2004) 769.

[47] J. Hoppe Filho, A. Gobbi, E. Pereira, V.A. Quarcioni, M.H.F. Medeiros, Matéria 22, 3 (2017) 1517.

(Rec. 29/10/2018, Rev. 15/01/2019, 10/03/2019, Ac. $11 / 03 / 2019)$ 